\title{
Effects of fish farming on seagrass (Posidonia oceanica) in a Mediterranean bay: seagrass decline after organic loading cessation
}

\author{
Olga DELGADO a ${ }^{\text {, Juanma RUIZ }}{ }^{\text {b }}$, Marta PÉREZ ${ }^{\text {c* }}$, Javier ROMERO ${ }^{\text {c }}$, Enric BALLESTEROS a

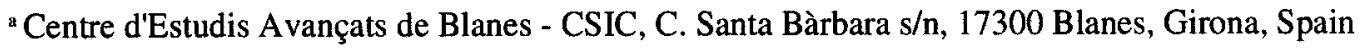 \\ ' Departamento de Ecología, Facultad de Biología, Universidad de Murcia, Campus de Espinardo, 30100 Espinardo, \\ Murcia, Spain \\ ${ }^{c}$ Departament d'Ecologia, Facultat de Biologia, Universitat de Barcelona, Avda. Diagonal 645, 08028 Barcelona, Spain
}

(Received 24 July 1997, revised 7 August 1998, accepted 14 August 98)

\begin{abstract}
The effects of fish farming on a seagrass (Posidonia oceanica) meadow at Fornells Bay, Minorca (Balearic Islands) were studied. Changes in plant and meadow features (e.g. shoot morphology, shoot density, biomass, rhizome growth, nutrient and soluble sugars concentrations...) in three stations along a transect from a disturbed (organic pollution due to fish cultures) to an undisturbed site were assessed. The fish culture had ceased in 1991; however, seagrass decline, already reported in a previous study for the period 1988-1990, was still taking place at the time of sampling (July 1994). Differences between stations were very clear; the station closest to the fish cages showed reduced shoot density, shoot size, underground biomass, sucrose concentration and photosynthetic capacities. In contrast, shoots from the most polluted station showed higher P-concentration in tissues and higher epiphyte biomass than the other two. Since water conditions had recovered completely by the time of the sampling mission, it is proposed that the persistence of the seagrass decline was due to the excess organic matter remaining in the sediment. (C) Elsevier, Paris / Ifremer / Cnrs / Ird
\end{abstract}

\section{aquaculture / seagrass / Posidonia oceanica / eutrophication / sediment characteristics}

Résumé - Effets de l'élevage de poissons sur les herbiers de Posidonia oceanica dans une baie méditerranéenne. Les effets de l'élevage de poissons en cages flottantes sur un herbier de Posidonia oceanica ont été étudiés dans la baie de Fornells (Minorque, îles Baléares). Des modifications dans les caractéristiques de la plante et de l'herbier (morphologie et densité des faisceaux, biomasse, croissance des rhizomes, teneurs en nutriments et en sucres solubles) sont observées en trois stations d'une radiale allant d'une zone polluée (par la matière organique due aux élevages de poissons) à une zone non polluée. Bien que l'élevage ait cessé en 1991, la dégradation notée en 1988-1990 s'est poursuivie jusqu'au moment de l'échantillonage décrit ici (juillet 1994). Les différences entre les stations sont très nettes : la proximité des cages est associée aux plus faibles valeurs de densité et taille des faisceaux, biomasse, teneur en saccharose et taux photosynthétique, tandis que dans cette même zone polluée, la concentration du phosphore dans les tissus et la biomasse des épiphytes sont maximales. La colonne d'eau ayant retrouvé son état initial après la disparition des élevages, la persistance de la dégradation pourrait être liée à des modifications du sédiment dont la teneur en matière organique est restée très élevée. (C) Elsevier, Paris / Ifremer / Cnrs / Ird

aquaculture / phanérogame marine / Posidonia oceanica / eutrophisation / caractéristique du sédiment

* Correspondence and reprints 


\section{INTRODUCTION}

The loss of seagrass meadows over extensive areas is a problem of major concern in the conservation and management of marine coastal ecosystems. Most of this loss has been attributed to human activities, among which the most damaging ones are industrial and domestic effluents and shore-line constructions which seem to increase nutrient and organic matter load and cause imbalances in the sediment budgets $[46,48]$. This situation is particularly prevalent in the Mediterranean, where the decline of the endemic seagrass Posidonia oceanica (L.) Delile due to anthropogenic activities has been repeatedly documented $[4,37,45]$. However, very little is known about seagrass meadow behaviour once the disturbance has ceased, although existing evidence points to an extremely low resilience of this system [33].

Fish farming induces high organic and nutrient loading into the surrounding water [5] that affects the ecosystem in a similar way to eutrophication. A significant fraction of this input accumulates in the sediment where anoxic conditions prevail $[52,53]$. Studies of the impact of marine aquaculture on benthic macrophyte communities, specially seagrass meadows, are scarce in the Mediterranean $[12,13,34]$ although all of them show a degradation of the vegetation under the influence of the farming installation. However, the precise nature of this degradation and the underlying mechanisms are unclear. Therefore, we examined in detail a Posidonia oceanica meadow where fish farming had recently ceased after several years of operation and a decline had been previously reported [13], analysing both meadow features and plant performances along a transect from the disturbed towards the undisturbed area. This correlational approach aims to obtain not only an assessment of the decline itself, but also some insight into the causal mechanisms.

\section{MATERIALS AND METHODS}

The study was carried out in Fornells Bay, situated on the north coast of Minorca (Balearic Islands, western Mediterranean, $40^{\circ} 03^{\prime} \mathrm{N}$ and $4^{\circ} 8^{\prime} \mathrm{E}$ ). Fornells Bay is a semienclosed bay, $4.4 \mathrm{~km}$ long and $1.5 \mathrm{~km}$ wide, with an average depth of $5.5 \mathrm{~m}$, connected to the open sea by a $300 \mathrm{~m}$ wide entrance. Benthic communities in soft sediments are characterized by the seagrasses Posidonia oceanica and Cymodocea nodosa (Ucria) Ascherson and the green algae Halimeda tuna (Ellis and Solander), Caulerpa pro- lifera (Forsskal) Lamouroux, Dasycladus vermicularis (Scopoli) Krasser and Flabelia petiolata (Turra) Nizamuddin $[13,20]$.

From 1986 to 1989, gilthead seabream Sparus auratus (L.) was farmed in nine floating cages $\left(100 \mathrm{~m}^{3}\right.$ each) anchored in the sediment. In 1990, 23 additional cages were installed, covering an area of $1500 \mathrm{~m}^{2}$. The amount of dry fodder used ranged from $22 \mathrm{Tm}$ per year from 1986 to 1989 to $77 \mathrm{Tm}$ per year in 1990. Farming ceased in summer 1991, although the cages and other structures were not dismantled until 1995.

Sampling and in situ measurements were carried out in July 1994. Three sampling stations were located at increasing distances [58-62 $\mathrm{m}$ (ST60), 78-82 $\mathrm{m}$ (ST80), and 98-102 $\mathrm{m}$ (ST100)] from the centre of the area in which the fish cages were installed. The stations were selected according to previous data on shoot density [13]. Based on these data, the most distant station (ST100) was considered as a control (non-polluted) site.

The sediment characteristics of the three stations were determined from samples collected using a diver-held core $(10 \mathrm{~cm}$ diameter), penetrating approximately $10 \mathrm{~cm}$ into the sediment. Three replicate cores were taken at each station, and immediately frozen. Organic matter in the sediment was analyzed for two depth fractions: (i) 0 $5 \mathrm{~cm}$, and (ii) $6-10 \mathrm{~cm}$. Organic matter content was measured as the decrease in weight after ashing the samples at $450{ }^{\circ} \mathrm{C}$ for $5 \mathrm{~h}$. Redox potential was measured in homogenised sediment samples at ambient temperature using a platinum electrode in conjunction with standard calomel reference Metrohm electrode. Potentials were transformed into redox potentials by adding the potential of the reference electrode $(+244 \mathrm{mV})$. Since disturbing samples can introduce errors in redox potential estimates, data were only used for comparative purposes.

Shoot density at each station was measured by counting the shoots present in ten replicate quadrats of $400 \mathrm{~cm}^{2}$. Above- and below-ground biomass were determined in samples obtained with a diver-held core $(16 \mathrm{~cm}$ diameter, [42]), penetrating to approximately $20 \mathrm{~cm}$ depth in the sediment. Two samples were taken at each station; these were immediately washed with running seawater using a fine sieve and sorted into (i) living leaves, (ii) living algae, (iii) living rhizomes, (iv) dead rhizomes, (v) living roots, (vi) dead roots, and (vii) fine undifferentiated fraction $(0.1-0.8 \mathrm{~cm})$. The plant material was dried at $70^{\circ} \mathrm{C}$ to constant weight. The criteria used in the fractioning 
and differentiation of below-ground parts are described in Francour [21].

The structural and morphological features of the plants were assessed using ten shoots, collected at random by a scuba diver at each station. For each shoot, the following descriptors were measured: number of leaves and, for each leaf, length, width, length of the leaf base and apex state (described as intact, broken, eaten by fish or by seaurchins, [8]). Epiphytes were removed using a razor blade, and leaves and epiphytes were weighed separately after drying at $70^{\circ} \mathrm{C}$ to constant weight.

Nutrient concentrations in plant tissues were analyzed in shoots and rhizomes. At each station, three replicated shoots and attached rhizomes were collected at random by scuba-divers. The plants were sorted into (i) old leaves, (ii) intermediate leaves, (iii) young leaves, and (iv) topmost $2 \mathrm{~cm}$ portion of the rhizome, dried to constant weight at $70^{\circ} \mathrm{C}$ and ground to a fine powder. To discriminate between young, intermediate and adult leaves, the criteria of Giraud [22] were used. Total nitrogen was determined using a Carlo Erba CHN elemental analyser, while total phosphorus was determined by a colorimetric method after a wet acid digestion in a microwave oven [30]. The carbohydrate content of the rhizomes was determined in aliquots of the samples used for nutrient determinations. Soluble carbohydrates were obtained from hot ethanol extracts $\left(80{ }^{\circ} \mathrm{C}\right)$. The extracts were evaporated to dryness at room temperature under a stream of air, redissolved in distilled water and analysed using resorcinol assay standardised to sucrose using a spectrophotometer [25]. Starch was extracted from the ethanolinsoluble residue in $\mathrm{KOH}(1 \mathrm{~N})$ and analysed spectrophotometrically using anthrone assay standardised to sucrose [54].

Net oxygen release at saturating irradiance (Pmax, [28]) by leaves and oxygen uptake by rhizomes were determined from changes in the dissolved oxygen concentration within $250 \mathrm{~mL}$ incubation bottles. Oxygen concentrations were measured with an Orbisphere Model 2610 oximeter to the nearest $0.01 \mathrm{mg} \mathrm{L}^{-1}$, after $1 \mathrm{~h}$ (for leaf oxygen production) and $2 \mathrm{~h}$ (for rhizome respiration) of incubation. Bottles were incubated in situ, suspended at $3 \mathrm{~m}$ depth in the study area and incubated at noon on clear sunny days; under these conditions, photon flux density is around $1000 \mu \mathrm{mol} \mathrm{m} \mathrm{m}^{-2} \mathrm{~s}^{-1}$, which largely exceeds saturation values for this species [3]. For leaf oxygen release measurements, $2 \mathrm{~cm}$ long, cpiphyte-frcc portions of the first adult leaf (the younger leaf with a distinct leaf base [22]) were used. Rhizome respiration was measured using the topmost $1 \mathrm{~cm}$ portion of the rhizome (about one year old; [40]). Four replicates were used in all cases.

Rhizome growth was determined by measuring the internodal distance among the insertion points of succesive leaf 'scales' (the remnant leaf petioles, which remains attached to the rhizome after leaf abcission); this gives the growth rate per plastochron interval (PI, [36]) time unit; to convert these data into absolute time units (years), lepidochronology was used $[9,39]$. This method relies on the cyclic annual variation in the thickness of the mentioned 'scales'. Ten replicates of orthotropic (vertical growing) rhizomes, up to $20 \mathrm{~cm}$ long, were taken at each station and used for lepidochronological analysis.

Differences between stations in the descriptors measured were tested using one-way ANOVA. Differences between stations and tissues in nutrient concentration were tested using two-way ANOVA. Tukey's honestly significant difference (HSD) test was used to locate pairwise differences between stations.

\section{RESULTS}

The organic matter content in the sediment (table I) at the three stations was very high, ranging from 9 to $16 \%$ of dry weight, with the highest values close to the fish culture cages. Redox potential at the three stations ranged from -10 to $120 \mathrm{mV}$.

Table I. Organic matter content of the sediment (as \% of dry weight). Values are mean \pm standard error, $n=3$.

\begin{tabular}{cccc}
\hline & ST60 & ST80 & ST100 \\
\hline $0-5 \mathrm{~cm}$ & $12.8 \pm 1.5$ & $14.2 \pm 5.5$ & $10 \pm 0.75$ \\
$5-10 \mathrm{~cm}$ & $16.5 \pm 0.75$ & $12 \pm 4$ & $9 \pm 2.75$ \\
\hline
\end{tabular}

Statistical significance of meadow and plant descriptors is summarised in table II. Shoot density decreased from ST100 to ST60, as did shoot size and, consequently, biomass per unit area (figures 2 and 3, table III). Macroalgal biomass seemed to incrcasc towards ST60 (figure 3), although this trend was only marginally significant. The specific composition of the macroalgae community changed, with a dominance of filamentous red algae, mainly Spyridia filamentosa, at ST60.

Live total below-ground (rhizome and root) biomass showed significant differences between stations, with 
Table II. Summary of one-way ANOVA results. Stations are $\mathrm{I}=\mathrm{ST} 60,2=\mathrm{ST} 80$ and $3=\mathrm{ST} 100$. Stations not differing signiticantly one from the other are underlined.

\begin{tabular}{|c|c|c|c|c|}
\hline \multirow[t]{2}{*}{ Dependent variable } & \multicolumn{2}{|c|}{$\%$ Variability } & \multirow[t]{2}{*}{$\mathbf{P}$} & \multirow{2}{*}{$\begin{array}{c}\text { Pairwise } \\
\text { differences }\end{array}$} \\
\hline & among stations & within stations & & \\
\hline Shoot density & 44 & 56 & $<0.001$ & 123 \\
\hline Shoot biomass & 54 & 46 & $<0.001$ & 123 \\
\hline Leaf length & 68 & 32 & $<0.001$ & 123 \\
\hline Leaf width & 30 & 70 & $<0.001$ & 123 \\
\hline Epiphyte biomass & 66 & 34 & 0.002 & 123 \\
\hline Algal biomass & - & - & n.s. & - \\
\hline Live below-ground biomass & 98 & 2 & 0.01 & $1 \underline{23}$ \\
\hline Net oxygen release & 40 & 60 & 0.04 & 123 \\
\hline Respiration & - & - & n.s. & - \\
\hline Sucrose & 71 & 29 & 0.04 & 123 \\
\hline Starch & - & - & n.s. & - \\
\hline
\end{tabular}

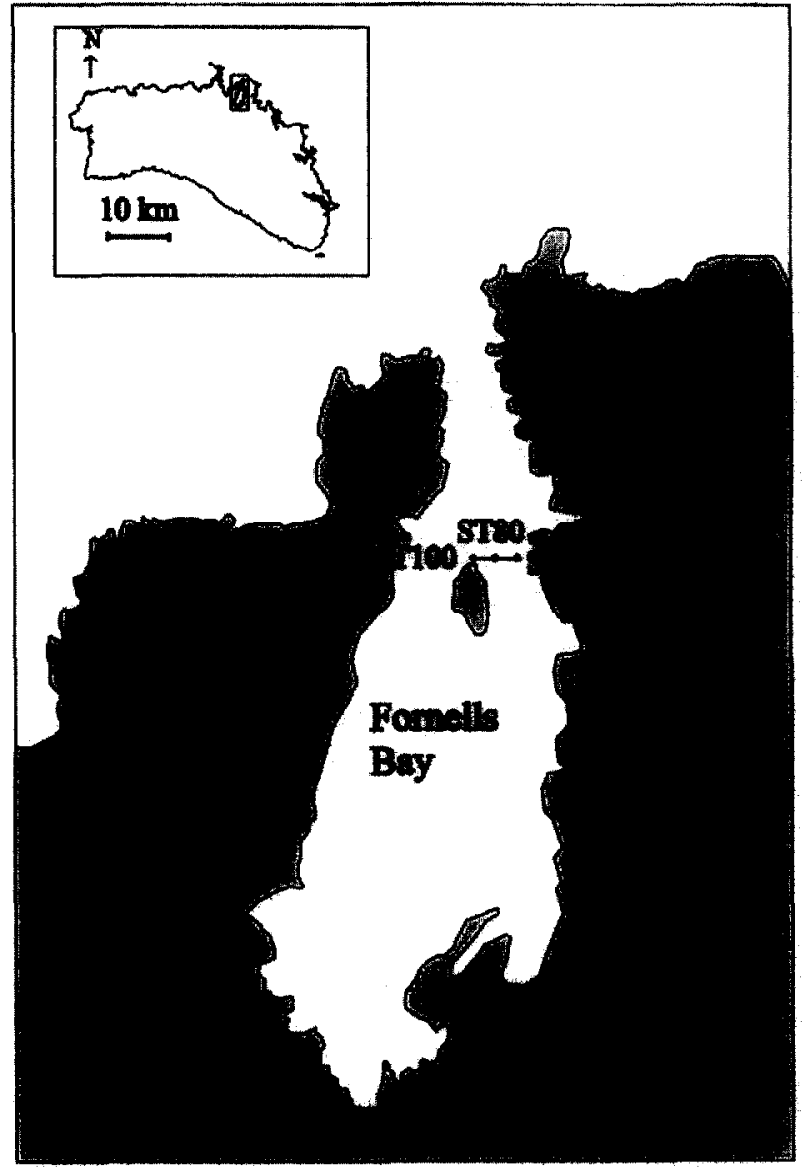

Figure 1. Map of Fornells Bay (Minorca Island, western Mediterranean) with the situation of the sampling stations.

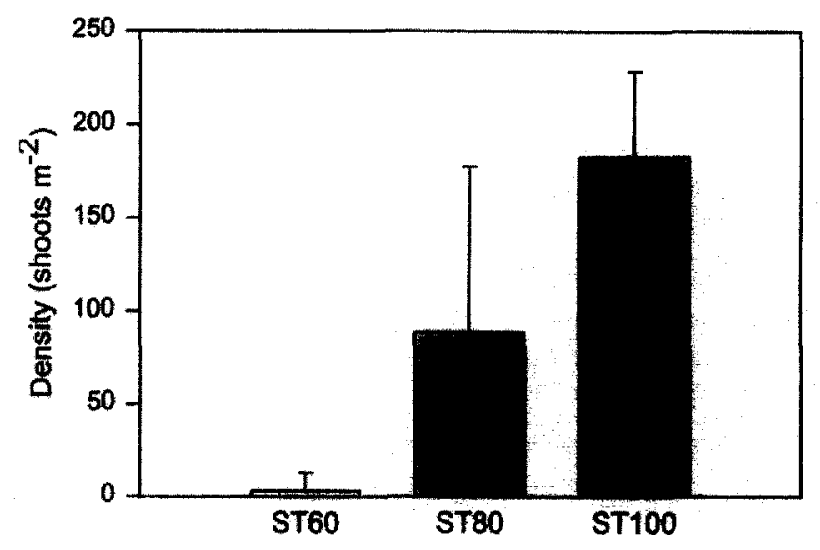

Figure 2. Shoot density at the three stations. Vertical bars are standard errors with $n=10$.

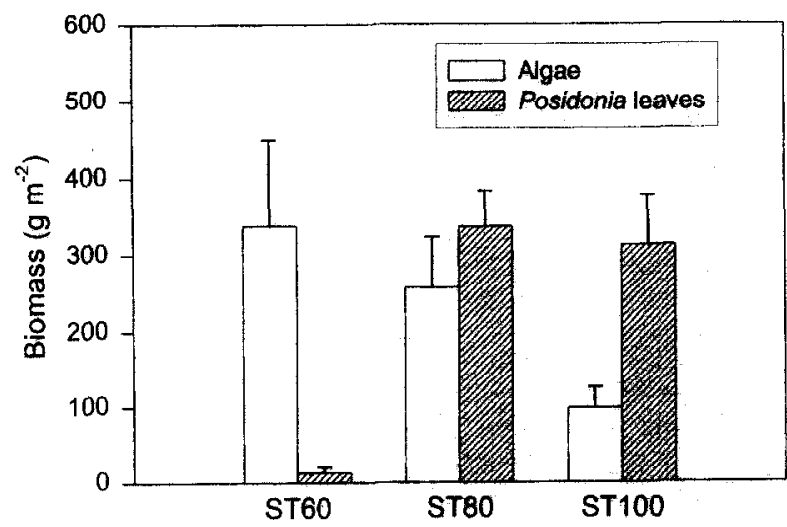

Figure 3. Above-ground biomass of Posidonia oceanica and biomass of macroalgae at the three stations. Vertical bars are standard errors with $n=3$. 
Table III. Shoot features (mean \pm standard error, with $n=3$ ).

\begin{tabular}{lccc}
\hline & ST60 & ST80 & ST100 \\
\hline $\begin{array}{l}\text { Number of leaves } \\
\text { per shoot }\end{array}$ & $5.7 \pm 0.25$ & $5 . \pm 0.32$ & $5.8 \pm 0.24$ \\
$\begin{array}{l}\text { Leaf length (cm) } \\
\text { (the longest) }\end{array}$ & $30.9 \pm 1.3$ & $38.6 \pm 2.7$ & $53.4 \pm 2.1$ \\
$\begin{array}{l}\text { Leaf width (cm) } \\
\text { (leaf 4) }\end{array}$ & $0.83 \pm 0.03$ & $0.87 \pm 0.04$ & $0.98 \pm 0.01$ \\
$\begin{array}{l}\text { Shoot biomass } \\
\text { (g shoot }{ }^{-1} \text { ) }\end{array}$ & $0.267 \pm 0.02$ & $0.355 \pm 0.04$ & $0.513 \pm 0.02$ \\
$\begin{array}{l}\text { Epithyte biomass } \\
\text { (g shoot }{ }^{-1} \text { ) }\end{array}$ & $0.312 \pm 0.02$ & $0.179 \pm 0.03$ & $0.199 \pm 0.01$ \\
$\begin{array}{l}\text { Intact apex } \\
(\%)\end{array}$ & 69 & 68 & 64 \\
$\begin{array}{l}\text { Broken apex } \\
(\%)\end{array}$ & 9 & 10 & 12 \\
$\begin{array}{l}\text { Eaten apex } \\
(\%)\end{array}$ & 22 & 22 & 23 \\
\end{tabular}

values ranging from $296 \mathrm{~g} \mathrm{~m}^{-2}$ at ST60 to up to $3000 \mathrm{~g}$ $\mathrm{m}^{-2}$ at ST100, whereas dead below-ground necromass did not (figure 4).

The shoots from the three stations (table III) were similar in terms of number of leaves per shoot (six on average) and grazing pressure $(67 \%$ with intact apex, $10 \%$ broken apex and $22 \%$ eaten apex on average) without significant differences among the three stations. However, they dif-

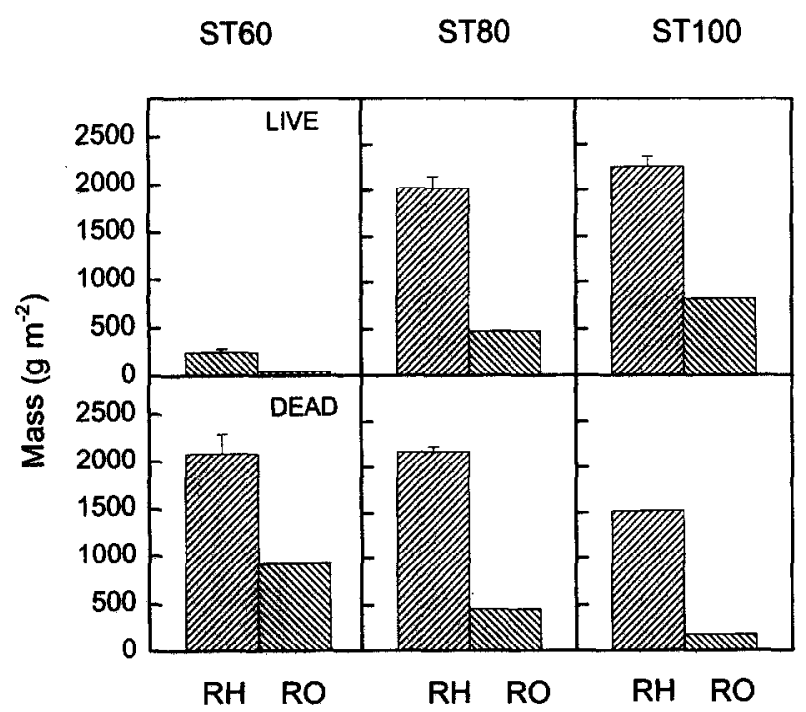

Figure 4. Below-ground biomass (above) and necromass (below) of Posidonia oceanica at the three stations. RH: rhizomes; RO: roots. Vertical bars are standard errors with $n=3$.

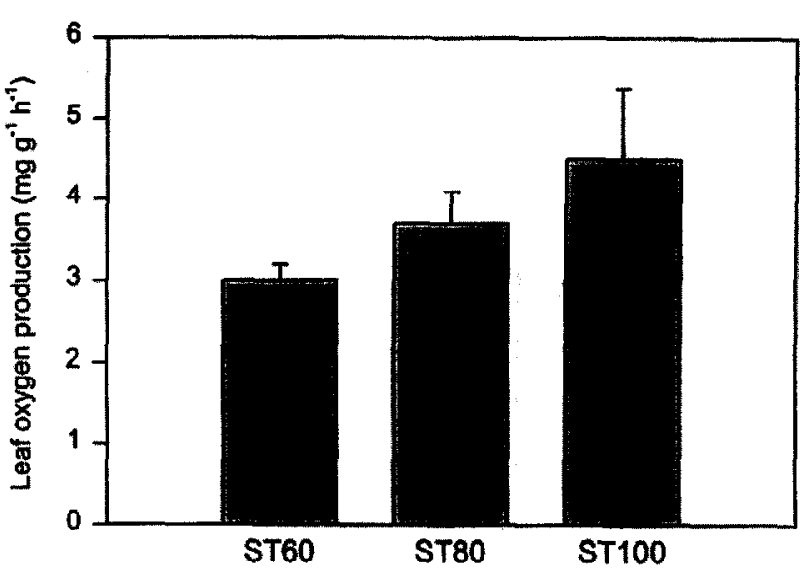

Figure 5. Leaf oxygen production of leaves from the different stations. Vertical bars are standard errors with $\mathrm{n}=3$.

fered in leaf width and length, the leaves from the sites closest to the fish cages being shorter and narrower. They also differed in epiphyte biomass, which was highest near the fish cages, and accounted for $53 \%$ of total shoot (Posidonia + epiphytes) biomass in ST60 and for 33 and $29 \%$ in ST80 and ST100, respectively.

No differences in $\mathrm{N}$ concentration in tissues and starch content in rhizomes were found (table IV). In contrast,

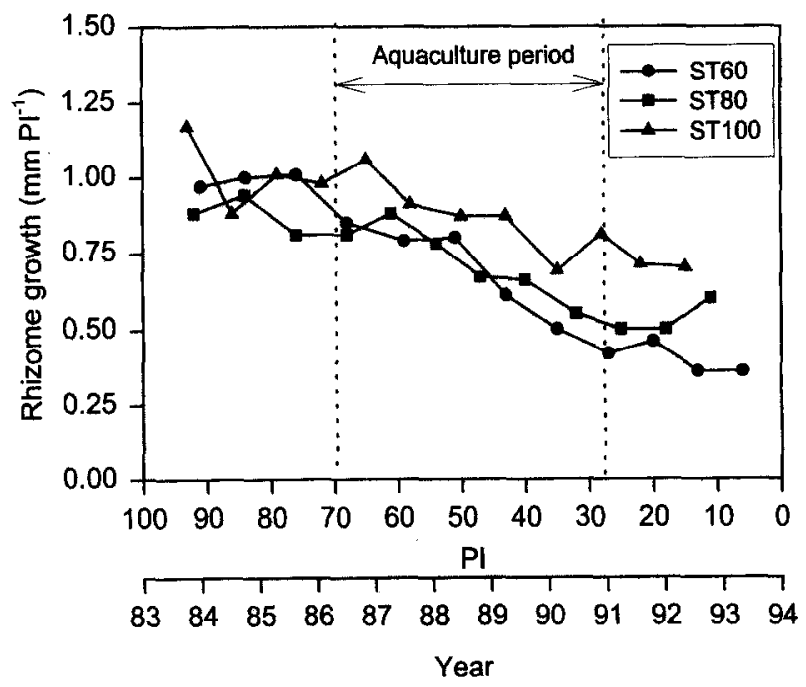

Figure 6. Rhizome growth at the three stations. Time axis (horizontal) is given in plastochrone interval (PI) units; an absolute estimate (years) is given tentatively. 
Table IV. Nutrient and carbohydrate concentration (as \% of dry weight) in the different fractions analyzed (mean \pm standard error with $\mathrm{n}=3$ ).

\begin{tabular}{|c|c|c|c|c|}
\hline & & ST60 & ST80 & ST100 \\
\hline Young leaves & $\begin{array}{c}\mathrm{N}(\%) \\
\mathrm{P}(\%) \\
\text { N/P (by atoms) }\end{array}$ & $\begin{array}{c}1.56 \pm 0.01 \\
0.396 \pm 0.006 \\
8.70\end{array}$ & $\begin{array}{c}1.49 \pm 0.02 \\
0.385 \pm 0.001 \\
8.17\end{array}$ & $\begin{array}{c}1.48 \pm 0.07 \\
0.342 \pm 0.026 \\
9.87\end{array}$ \\
\hline Intermediate leaves & $\begin{array}{l}\mathrm{N}(\%) \\
\mathrm{P}(\%) \\
\mathrm{N} / \mathrm{P}\end{array}$ & $\begin{array}{c}1.22 \pm 0.03 \\
0.292 \pm 0.008 \\
9.27\end{array}$ & $\begin{array}{c}1.24 \pm 0.03 \\
0.257 \pm 0.015 \\
10.73\end{array}$ & $\begin{array}{c}1.15 \pm 0.19 \\
0.276 \pm 0.011 \\
9.41\end{array}$ \\
\hline Aduit leaves & $\begin{array}{c}\mathrm{N}(\%) \\
\mathrm{P}(\%) \\
\text { N/P (by atoms) }\end{array}$ & $\begin{array}{c}0.75 \pm 0.01 \\
0.122 \pm 0.005 \\
8.68\end{array}$ & $\begin{array}{c}0.70 \pm 0.01 \\
0.165 \pm 0.009 \\
9.44\end{array}$ & $\begin{array}{c}0.82 \pm 0.01 \\
0.178 \pm 0.004 \\
10.25\end{array}$ \\
\hline Rhizomes & $\begin{array}{c}\mathrm{N}(\%) \\
\mathrm{P}(\%) \\
\text { SCH }(\%) \\
\text { Starch }(\%)\end{array}$ & $\begin{aligned} 1.51 & \pm 0.03 \\
0.214 & \pm 0.002 \\
7 & \pm 0.98 \\
7.8 & +0.93\end{aligned}$ & $\begin{aligned} 2.06 & \pm 0.19 \\
0.114 & \pm 0.003 \\
9 & \pm 1.27 \\
7.2 & \pm 0.59\end{aligned}$ & $\begin{aligned} 1.79 & \pm 0.15 \\
0.148 & \pm 0.006 \\
11 & \pm 0.66 \\
6.9 & \pm 0.43\end{aligned}$ \\
\hline
\end{tabular}

$P$ concentration in the leaves from the station closest to the fish cages (ST60) was significantly higher than that at the other two stations, and $\mathrm{N}: \mathrm{P}$ atomic ratio was thus lower at this station (ST60) (table $I V$ and V). Sucrose content in rhizomes was significantly higher at ST100 than at the other two stations (table II).

Table V. Summary of two-way ANOVA results for tissue $P$ concentration. Results for $\mathrm{N}$ concentration are not shown (differences among stations for $\mathrm{N}$ concentration, $\mathrm{p}=0.4$ ).

\begin{tabular}{lccc}
\hline Variable & $\%$ Variability & $\mathbf{P}$ & $\begin{array}{c}\text { Pairwise } \\
\text { differences }\end{array}$ \\
\hline Station & 4 & 0.001 & 123 \\
Fraction & 87 & $<0.001$ & \\
Interaction & 3 & 0.1 & \\
Error & 6 & & \\
\hline
\end{tabular}

Net oxygen release differed significantly between ST60 and ST100 with a $50 \%$ increase at ST100 (figure 5). Rhizome respiration did not show significant differences between stations with values ranging from 0.14 to $0.17 \mathrm{mg} \mathrm{g}^{-1} \mathrm{~h}^{-1}$.

At the three stations studied, the rhizome growth rate displayed a recent and progressive decrease which apparently occurred at the onset of fish culture activities in 1986 (figure 6). The oldest rhizome segments showed growth of around $0.90 \mathrm{~mm}(\mathrm{PI})^{-1}$, while the values in recent segments were much lower, around $0.75 \mathrm{~mm}\left(\mathrm{PI}^{-1}\right)$ at ST100 and $0.50 \mathrm{~mm}(\mathrm{PI})^{-1}$ at ST80 and ST60. The abandonment of fish farming in 1991 was not reflected by a significant increase in rhizome growth in any of the plants collected at the three stations, only a mild recovery was observed in plants at ST80.

\section{DISCUSSION}

The fish farming operations carried out in Fornells Bay for four years had dramatic consequences on the surrounding Posidonia oceanica meadow, as described here and previously documented [13]. An increased organic load, caused by excess fodder and fish faeces, seems to be the immediate cause of the seagrass decline. However, the mechanisms involved in this decline appear to be relatively complex.

Part of the organic matter derived from the cages becomes mineralized in the water, and thereby releases nutrients. These nutrients enhance phytoplankton [5] epiphyte and macroalgal growth which in turn reduce the light available to seagrasses $[7,32,47,49,51]$. A decrease in shoot density and biomass has been reported as a common response of seagrasses to natural or artificial light reduction [10, $16,17,35,41]$. Results obtained here are consistent with this finding: in effect, a clear gradient describing the decline in shoot density and shoot biomass appears from the least disturbed to the most disturbed stations, together with an increase in the epiphyte biomass.

However, it has to be remembered that fish farming activity was interrupted in 1991; in spite of this, not only has no recovery taken place, but decline is still occuring. This 
can be concluded by comparing our data to those previously reported [13]: the size of the bare area beneath the cages appears to be greater and shoot density in the vegetated zone is lower; for example, we found a shoot density, at ST100, of $183 \pm 46$ shoots $\mathrm{m}^{-2}$ in July 1995 , while the mentioned authors reported a shoot density of $340 \pm$ 41 shoot $\mathrm{m}^{-2}$ for the same station in July 1990 . Since water column features (nutrient concentrations and water turbidity) had been re-established at the time of the sampling described here (A. Martínez, unpublished observations), the reason for this persistent decline must be linked to sediment characteristics.

Due to the relatively low depth of the site (around $6 \mathrm{~m}$ ), a significant fraction of the organic matter input is incorporated into the sediment, and mineralized there, resulting in a high organic matter content in the sediment (compared with undisturbed meadows along the Mediterranean coast, where organic content ranges from 1 to $4.5 \%$; [26]) and low redox potentials (compared to redox potentials of $150 \mathrm{mV}$ in an undisturbed meadow, M.A. Mateo, unpublished results). Under these conditions, anoxia prevail and sulfide compounds are formed due to the oxidation of the organic material [24]. It is known that the accumulation of reduced compounds have toxic effects on seagrasses, as shown by the direct relationship between sediment sulphide and mortality in Thalassia testudinum [11], especially when the potential for utilization of the available light is reduced due to eutrophication [23]. Another effect of sediment hypoxia is that all the oxygen requirements of the below-ground organisms have to be met by oxygen transport from the leaves [50]. Oxygen deficit increases the periods of root hypoxia, which can interfere with $\mathrm{N}$ metabolism [43], and hence with seagrass growth and vitality. Moreover, reducing conditions in the sediment can alter the system nitrogen budget, mostly by increasing denitrification which has been shown to play a significant role in Posidonia oceanica meadows [29, 31].

In effect, the nutrient concentration in the leaves indicates a clear nutrient imbalance. Nitrogen concentration in leaves $(0.70-1.49 \%$, relative to dry weight) was below the median value estimated for seagrasses $(1.8 \%,[19])$, while phosphorus concentration in leaves $(0.16-0.40 \%)$ was above $(0.2 \%$; $[2,15,19,44])$. Consequently, N:P atomic ratios (8.2 to 10.3) were well below the average optimum ratio of 30 , reported for aquatic macrophytes by Atkinson and Smith [6], the median ratio of 24, reported for a set of 27 species of seagrasses by Duarte [19] or the value of 31.5 obtained by Alcoverro et al. [2] for nutrient-sufficient plants. All this would suggest a $\mathrm{N}$-limited plant productivity in these meadows, in contrast with the more generalised P-limited productivity of Posidonia oceanica and other mediterranean macroalgae and seagrasses $[1,19,38]$. A shift of P-limited macrophytic productivity towards a predominantly $\mathrm{N}$-limitation has been proposed as a sign of increasing eutrophication where denitrification processes may take on greater importance [14].

The data presented also suggest a carbon imbalance associated with the organic loading. Pm (net oxygen release at saturating irradiance) is much lower (about $50 \%$ ) in ST60 station than at ST80 and ST100. The immediate consequence is a limitation of carbon gains. Combining data from table $I V$ and figure 4, it is shown that the total amount of reserves (soluble sugars plus starch) per unit area is about ten-fold higher in the ST- 80 and ST- 100 stations that in the ST-60 station; this implies that the carbon demand during the period of negative carbon balance of the plant (winter, [1]) will not be met by such reserves in ST-60, leading to shoot mortality and/or shoot size reduction at the beginning of the productive season; this, as well as a lower value of Pm, would in turn result in a reduction in the excess carbon at the time of the year when net carbon gains are at their maximum (summer, [1]) with consequently lower levels of stored carbohydrates.

Moreover, the high below-ground biomass of this plant (figure 5), which is among the highest reported for seagrasses [18], implies a high oxygen demand [1] which cannot be met either by oxygen transport from the leaves (due to the partial mortality of shoots, and to the reduced photosynthetic capacities) or by the surrounding sediment, which is clearly hypoxic. This leads to the mortality of below-ground organisms, and since these organisms are of crucial importance for plant winter survival, due to their role as storage sites [1, 42], this, in turn, causes shoot mortality.

The results presented here, although correlative, add information to the existing knowledge on the effects of organic loading on seagrasses. Moreover, there is an unprecedented, as far as we are aware, observation on the fact that a man-made disturbance at a given spatial (some hundreds of square metres) and temporal (several years) scale can propagate its negative effects on the meadow survival well beyond the spatio-temporal dimension of the disturbance, most probably associated to the modification of the conditions of the meadow sediment. Sea- 
grasses are key ecosystems, and are very sensitive to anthropic disturbances [27]; in the case of $P$. oceanica, additional concern arises due to its very low recovery capacity [33]. In the light of these considerations, the reportcd obscrvation of sustained decline well beyond the interruption of the organic loading proves the necessity for extreme caution in mangement decisions if seagrass ecosystems are to be conserved.

\section{Acknowledgements}

This project was funded by the Direccio General de Pesca $i$ Cultius Marins del Govern Balear. The authors are sincerely grateful to Sebastià Pou, Antoni Grau and Francesc Riera for their valuable support and assistance during the field work and to Jud Kenworthy for his comments on the manuscript.

\section{REFERENCES}

[1] Alcoverro T., Ecologia de la producció de la fanerògama marina Posidonia oceanica (L.) Delile, $\mathrm{PhD}$ Thesis, Barcelona (1995).

[2] Alcoverro T., Romero J., Duarte C., López N.I., Spatial and temporal variations in nutrient limitation of seagrass Posidonia oceanica growth in the NW Mediterranean, Mar. Ecol. Prog. Ser. 146 (1997) 155-161.

[3] Alcoverro T., Manzanera M., Romero J. (in press), Seasonal and age-dependent variability of Posidonia oceanica (L.), Delile photosynthesis and respiration, J. Exp. Mar. Biol. Ecol.

[4] Ardizzone G.D., Pelusi P., Yield and damage evaluation of bottom trawling on Posidonia meadows, in: Boudouresque C.F., Jeudy de Grissac A., Olivier J. (Eds.), International Workshop on Posidonia oceanica beds, GIS Posidonie, Marseille, 1 (1984) 63-72.

[5] Arzul G., Clement A., Pinier A., Effects of phytoplankton growth of dissolved substances produced by fish farming, Aquatic Living Resources 9 (2) (1996) 95-102.

[6] Atkinson M.J., Smith S.V., C:N:P ratios of benthic marine plants, Limnol. Oceanogr. 28 (1983) 568-574

[7] Borum J., Development of epiphytic communities on eelgrass (Zostera marina) along a nutrient gradient in a Danish estuary, Mar. Biol. 87 (1985) 211-218.

[8] Boudouresque C.F., Meinesz A., Découverte de l'herbier de Posidonies, Cahiers Parc National Port Cros 4 (1982).

[9] Boudouresque C.F., Crouzet A., Pergent G., Un nouvel outil au service de l'étude des herbiers à Posidonia oceanica: la Lépidochronologie, Rapp. Comm. int. Mer Médit. 28 (3) (1983) 111-112.

[10] Bulthuis D.A., Effects of in situ light reduction on density and growth of the seagrass Heterozostera tasmanica (Martens ex Aschers) den Hartog in Western Port, Victoria, Australia, J. Exp. Mar. Biol, Ecol, 61 (1983) 91-103.

[11] Carlson Jr. P.R., Yabro L.A., Barber T.R., Relationship of sediment sulfide to mortality of Thalassia testudinum in Florida bay, Bull. Mar. Sci. 54 (3) (1994) 733-746.

[12] Casabianca de M.L., Laugier T., Collard D., Impact of shellfish farming eutrophication on benthic macrophyte communities in the Thau Lagoon, France, Aquaculture International 5 (4) (1997) 301-314.
[13] Delgado O., Grau A., Pou S., Riera F., Massuti C., Zabala M., Ballesteros E., Seagrass regression caused by fish cultures in Fornells Bay (Menorca, Western Mediterranean), Oceanol. Acta 20 (3) (1997) 557-563.

[14] Delgado O., Lapointe B.E., Nutrient-limited productivity of calcareous versus fleshy macroalgae in a eutrophic, carbonaterich tropical marine environment. Coral Reefs 13 (1994) 151159.

[15] Delgado O., Vidal M., Phosphorus cycling in Mediterranean seagrass ecosystems: phosphorus content of vegetal tissues and sedimentsi, in: Boudouresque C.F., Meinesz A., Fresi E., Gravez V. (Eds.), International Workshop on Posidonia oceanica beds, GIS Posidonie, Marseille, 2 (1989) 93-100.

[16] Dennison W.C., Effects of light on seagrass photosynthesis, growth and depth distribution, Aquat. Bot. 27 (1987) 15-26.

[17] Dennison W.C., Alberte R.S., Photosynthetic responses of Zostera marina L. (eelgrass) to in situ manipulations of light intensity, Oecologia 55 (1982) 137-144.

[18] Duarte C.M., Temporal biomass variability and production/ biomass relationships of seagrass communities, Mar. Ecol. Prog. Ser. 51 (1989) 269-276.

[19] Duarte C.M., Seagrass nutrient content, Mar. Ecol. Prog. Ser. 67 (1990) 201-207.

[20] Fornòs J.J., Forteza V., Jaume C., Martínez-Taberner A., Present-day Halimeda carbonate sediments in temperate Mediterranean embayments: Fornells, Balearic Islands, Sediment. Geol. 75 (1992) 283-293.

[21] Francour P., Dynamique de l'écosystème à Posidonia aceanica dans le Parc National de Port- Cros, Analyse des compartiments matte, litière, fauna vagile, échinodermes et poissons, PhD Thesis. Univ. Aix-Marseille II (1990).

[22] Giraud G., Sur une méthode de mesure et de comptage des structures foliaires de Posidonia oceanica (L.), Delile, Bull. Mus. Hist. Nat. Marseille 39 (1979) 33-39.

[23] Goodman J.L.. Moore K.A., Dennison W.C., Photosynthetic responses of eelgrass (Zostera marina $\mathrm{L}$.) to light and sediment sulfide in a shallow barrier island lagoon, Aquat. Bot. 50 (1) (1995) $37-47$

[24] Hakanson L., Jansson J., Principles of lake sedimentology, Springer, Berlin (1983). 
[25] Huber S.C., Israel D.W., Biochemical basis for partitioning of photosynthetically fixed carbon between starch and sucrose in soybean (Glycine max Merr.) leaves, Plant. Physiol. 69 (1982) $691-696$.

[26] Invers O., Pérez M., Romero J., Alkaline phosphatase activity as a tool for assessing nutritional conditions in the seagrass Posidonia oceanica (L.) Delile,. Sci. Mar. 59 (Supl. 1) (1995) 41-47.

[27] Larkum A.W.D., McComb E.A.J., Shepherd S.A., Biology of seagrasses, A treatise on the hiology of seagrasses with special reference to the Australian region, Elsevier, New York, 1989.

[28] Lobban C.S., Wynne M.J., The Biology of Seaweeds, Blackwell Scientific, Oxford, 1981.

[29] López N.I., Duarte C.M., Vallespinós F., Romero J., Alcoverro T., Bacterial activity in seagrass (Posidonia oceanica) sediments, J. Mar. Biol. Ecol. 187 (1995) 39-49.

[30] Mateo M.A., Sabaté S., Wet digestion of vegetable tissue using a domestic microwave oven, Anal. Chem. 279 (1993) 273279.

[31] Mateo M.A., Romero J., Detritus dynamics in the seagrass Posidonia oceanica: elements for an ecosystem carbon and nutrient budget, Mar. Ecol. Prog. Ser. 151 (1997) 43-53.

[32] Mcglathery K.J., Nutrient and grazing influences on a subtropical seagrass community, Mar. Ecol. Prog. Ser. 122 (1-3) (1995) 239-252.

[33] Meinesz A., Lefevre J.L., Régénération d'un herbier de Posidonia oceanica quarante années après sa destruction par une bombe dans la rade de Villefranche (Alpes-Maritimes, France), in: Boudouresque C.F., Jeudy de Grissac A., Olivier J., (Eds.) International Workshop on Posidonia oceanica beds, GIS Posidonie, Marseille, 1 (1984) 39-44.

[34] Mendez S., Pergent G., Pergent-Martini C., Impact of fish farming facilities on coastal ecosystems, Proceedings of the Third conference on the Mediterranean Coastal Environment, Qawra, Malta (1997) 197-211.

[35] Neverauskas V.P., Response of a Posidonia community to prolonged reduction in light, Aquat. Bot. 31 (1988) 361-366.

[36] Patriquin D.G., Estimation of growth rate, production and agc of the marine angiosperm Thalassia testudinum Koning, Carib. J. Sci. 13 (1-2) (1973) 111-123.

[37] Pérès J.M., Picard J., Causes de la raréfaction et de la disparition des herbiers de Posidonia oceanica sur les côtes françaises de la Méditerranée, Aquat. Bot. 1 (1975) 133-139.

[38] Pérez M., Romero J., Duarte C.M., Sand-Jensen K., Phosphorus limitation of Cymodocea nodosa growth, Mar. Biol. 109 (1991) 129-133.

[39] Pergent G., Boudouresque C.F., Crouzet A., Meinesz A. Cyclic changes along Posidonia oceanica rhizomes (lepidochronology): present state and perspectives, PSZNI: Marine Ecology 10 (3) (1989) 221-230.

[40] Pergent G., Romero J., Pergent-Martini C., Mateo M.A., Boudouresque C.F., Primary production, stocks and fluxes in the
Mediterranean seagrass Posidonia oceanica, Mar. Ecol. Prog. Ser. 106 (1994) 139-146.

[41] Philipart C.J.M., Effects of shading on growth, biomass and population maintenance of the intertidal seagrass Zostera noltii Hornem in the Dutch Wadden Sea, J. Exp. Mar. Biol. Ecol. 188 (2) (1995) 199-213.

[42] Pirc H., Below-ground biomass of Posidonia oceanica (L.) Delile and its importance to the growth dynamics, in: Proceedings International Symposium on Aquatic Macrophytes, Nijmegen (1983) p. 7781.

[43] Pregnall A.M., Smith R.D., Kursar T.A., Alberte R.S., Metabolic adaptation of Zostera marina (eelgrass) to diurnal periods of root anoxia, Mar. Biol. 83 (1984) 141-147.

[44] Romero J., Pérez M., Alcoverro T., Mateo M.A., SánchezLizaso J.L., Production ecology of Posidonia oceanica (L.) Delile meadows in Nueva Tabarca marine reserve: Growth, biomass and nutrient stocks along a bathymetric gradient, Oecol. Aquat. 11 (1998) 113-123.

[45] Sánchcz-Lizaso J.L., Guillćn-Nicto J.E., Ramos-Esplá A.A., The regression of Posidonia oceanica meadows in El Campello (Spain), Rapp. Comm. Int. Mer. Médit. 32 (7) (1990).

[46] Shepherd S.A., McComb A.J., Bulthuis D.A., Neverauskas V., Steffensen D.A., West R., Decline of seagrases, in: Larkum A.W.D., McComb A.J., Shepherd S.A. (Eds.), Biology of seagrasses, A treatise on the biology of seagrasses with special reference to the Australian region, Elsevier, New York, 1989.

[47] Short F.T., Burdick D.M., Kaldy III J.E., Mesocosm experiments quantify the effects of eutrophication on eelgrass, Zostera marina, Limnol. Oceanogr. 40 (4) (1995) 740-749.

[48] Short F.T., Wyllie-Echeverria S., Natural and human-induced disturbance of seagrasses, Environmental Conservation 23 (1) (1996) 17-27.

[49] Silberstein K., Chiffings A.W., McComb A.J., The loss of seagrass in Cockburn sound, western Australia, III, The effect of epiphytes on productivity of Posidonia australis Hook. F., Aquat. Bot. 24 (1986) 355-371.

[50] Smith R.D., Dennison W.C., Alberte R.S., Role of seagrasses photosynthesis in root aerobic processes, Plant Physiology 74 (1984) 1055-1058.

[51] Tomasko D., Lapointe B.E., Productivity and biomass of Thalassia testudinum as related to water column nutrient availability and epiphyte levels: field observations and expcrimental studies, Mar. Ecol. Prog. Ser. 75 (1991) 9-17.

[52] Troell M., Berg H., Cage fish farming in the tropical Lake Kariba, Zimbabwe: impact and biogeochemical changes in sediment, Aquaculture research 28 (7) (1997) 527-544.

[53] Wu R.S.S., The environmental impact of marine fish culture: towards a sustainable future, Mar. Poll. Bull. 31 (4-12) (1997) 159-166.

[54] Yemm E.W., Willis A.J., The estimation of carbohydrates in plant extracts by anthrone, Biochem. J. 57 (1954) 508-514. 